\title{
6 \\ Turning the Colonial Tide: Working towards a Reconciled Ethnomusicology in Australia
}

\author{
Elizabeth Mackinlay and Katelyn Barney
}

\section{Introduction}

This chapter is a story about reconciliation. It is a story about the vision one person had for a music research organisation to be courageous and enter into discussion about disciplinary collusion in a coloniality of being. It is a story of what happened to begin to turn the colonial tide. On 28 May 2000, a milestone was reached in the process of reconciliation between Indigenous and non-Indigenous Australians. Hundreds upon thousands of Australians walked across Sydney Harbour Bridge and other significant landmarks around the country in a groundswell of support for improving relationships between Indigenous and non-Indigenous peoples. This gesture of support for Indigenous reconciliation put in place the impetus for institutional change, and placed renewed attention on the need for researchers and research organisations to reconsider the ways in which they engage in research with Indigenous Australian peoples.

As a discipline with a deeply embedded and implicated colonial history, ethnomusicology in Australia sought to find the means in which to turn the tide and address the spectre of colonialism in practical and meaningful ways. In this chapter, we turn the clock back to 1998 to explore the ways in which Stephen Wild sought to challenge the colonial paradigm for 
research in ethnomusicology in Australia by finding ways to enter into dialogue with Indigenous Australian peoples on matters of sovereignty over country, knowledge, and representation through his work in relation to the Musicological Society of Australia (MSA). Specifically of interest in this chapter is Wild's foresight in the form of a constitutionally recognised and mandated 'Welcome to Country' and the Indigenous music think tank.

In this chapter, Wild's contribution to Australian music research will be explored in relation to a burgeoning decolonial agenda to enter into a different way of doing business with Indigenous Australian peoples in ethno/musicological research more broadly. Both of us worked with Wild at various times on initiatives associated with privileging Indigenous Australian ways of being, knowing, and doing in relation to performance and disciplinary practices, and throughout this chapter, we have chosen to demonstrate that professional relationship from here on by using our first names. For us, this is not an unusual discursive move as relationships and the appropriate naming of those relationships, in and of themselves, are considered central principles in researching with Indigenous Australian peoples and in the context of Indigenous Australian studies (Barney, Nakata, and Shannon 2014; Brown 2010). Another matter worth noting from the outset is the ways in which we have relied upon individual disciplinary and institutional memory to research the history of the 'Welcome to Country' policy. Record-keeping practices in professional societies and organisations are marked differently now than they were then and, in addition to this, those of us in the MSA community who were involved in these dialogues at the time will all have our own recollection of the events as they happened. The discussion we present here is from our own positioning, which necessarily includes our theoretical, political, and personal standpoints.

We first provide an explanation and discussion of 'why' this chapter and 'why now' in terms of our positioning as ethnomusicological researchers and the current theoretical climate in Indigenous Australian studies in which we find ourselves. We then give a historical account of the events leading up to the constitutional change in the MSA and consider the tensions inherent within reconciliation discourses and processes within colonial disciplines such as ethnomusicology. Our discussion then turns to consider the important activities of the Indigenous music think tank and conclude by considering current moves by the MSA to further Wild's agenda. 


\section{Our positioning, our purpose}

Our purpose in writing this chapter is twofold. First, both of us have been doing, being, and knowing in and around issues of coloniality and decoloniality in Indigenous research and ethnomusicology for some time. The ways in which the 'colonial tide' in Australian music research has ebbed and continues to flow matters to us because of our ongoing relationships and responsibilities to the Indigenous Australian peoples and communities we work with, and the ethical and urgent need for our work to move away from being about just-us to justice. We have asked questions in our research around the ways in which ethnomusicology and other disciplines such as education, continue to use white race, power, and privilege in theoretical, epistemological, and pedagogical ways as part of the ongoing colonial project. This is one of the central concerns we hold, that is, the roles, responsibilities, and rights of disciplinary bodies, practices, and performativities to challenge coloniality and move closer to a decoloniality of being.

Liz is a non-Indigenous woman who grew up on Watharung country in western Victoria. She began her academic career in ethnomusicology in 1994 working with Yanyuwa, Garrwa, Mara, and Kudanji people in the remote town of Burrulula in the southwest Gulf of Carpentaria in the Northern Territory of Australia and found herself in the position of teaching in the field of Indigenous Australian studies soon after. Liz is married to a Yanyuwa man and is mother to their two children. Her PhD in ethnomusicology combined with higher-education teaching experience led her to embark on a second $\mathrm{PhD}$, this time in education, where she explored the performativity of power, race, and relationship in Indigenous Australian studies. Over time then, her research focus has turned to her positioning as a non-Indigenous woman in relation to and in relation with Indigenous peoples, knowledges, and cultures. Liz's work has increasingly focused on issues of social justice and education for Aboriginal and Torres Strait Islander people (e.g. Mackinlay 2008, 2011), and in recent years she has become passionate about the power and privilege that non-Indigenous educators have to enact a 'pedagogy of the heart' (Mackinlay 2011), which is ultimately about empowerment and self-determination for Indigenous Australians. She now describes much of her work as 'applied' in the sense that it is undertaken in collaboration with Indigenous communities and driven by their needs and agendas (Mackinlay 2010). In relation to the 
discussion here, Liz worked with Stephen to draft the guidelines for the 'Welcome to Country' that would become part of MSA standard operational procedure.

Like Liz, Katelyn's background is in music and Indigenous studies, and she completed a $\mathrm{PhD}$ working with Indigenous women performing contemporary music in 2006. Since then her research has shifted to a collaborative framework, and she has undertaken a number of research partnerships with Indigenous researchers and colleagues (see Barney 2014). With Torres Strait Islander performer and researcher Lexine Solomon, she explored how Torres Strait Islander women express their identities through contemporary music (Barney and Solomon 2010); and with Monique Proud, an Aboriginal researcher, her work has considered contemporary music-making in her own community of Cherbourg in Queensland, Australia (Barney and Proud 2014). From Kate's perspective, collaborative research between Indigenous and non-Indigenous people holds the potential to help bridge the gulf, to allow non-Indigenous and Indigenous people to work equally together, to learn from each other, and to resist oppression of Indigenous people through inclusion as co-researchers. Kate had the opportunity to engage in discussions with Stephen and other ethnomusicologists at a symposium at Griffith University in 2011 about the importance of preserving Indigenous Australian music, and this led to the development of the Australia and New Zealand Regional Committee of the International Council for Traditional Music position statement on the needs for greater support and action in relation to preserving Aboriginal and Torres Strait Islander music and dance (International Council for Traditional Music-Australia and New Zealand 2011).

Second, in writing this chapter we are interested in continuing the mixed-up theoretical-political-ethical conversation around decoloniality in ethnomusicological research and its relationship to disciplinary practice. In many ways this chapter, and indeed the resistant work of Stephen Wild, is set against the backdrop of what we might think of as the 'white noise' of music research. The 'Welcome to Country' was an attempt to break the monotony of colonial dominance in Australian music, and acknowledge, validate, and privilege Indigenous Australian sovereignties in that space; in essence, to interrupt the 'white noise'. It is important to think about other kinds of work being undertaken at that time in relation to issues of race, whiteness, Indigenous peoples, and music. In 2000, Radano and Bohlman's text Music and the Racial 
Imagination (2000) arguably broke the silence around critical discussion of race in relation to music: 'A specter lurks in the house of music, and it goes by the name of race. For most observers, it hovers and haunts, barely noticed, so well hidden is it beneath the rigors of the scholarly apparatus' (ibid.: 1); they wrote and invited consideration by musicologists and music researchers more broadly, of the ways in which music is racially heard. They urged reflection upon the ways in which race itself enabled access across temporal and social distances to the musics of Others. Such relational encounters, they suggested, worked paradoxically to at once musically construct and imagine the sounds of Others, while situating the sounds of the West at the 'centre' (ibid.: 16). Radano and Bohlman's work encouraged music scholars to engage theoretically, discursively, and practically with the challenges put forward by critical race theory and whiteness studies (e.g. McIntosh 1992; Frankenburg 1993; Harris 1993) in order to think differently about the white powers, privileges, perspectives, and performativities our research work held and enacted as particular kinds of colonising listeners, fieldworkers, analysts, and writers.

'Welcome to Country' is essentially about the recognition of Indigenous Australian sovereignty. The work of Moreton-Robinson on 'white possessive logic' seems useful in understanding where the MSA's move to instigate a 'Welcome to Country' fits into this colonial and racialised landscape of music research. In her critiques of whiteness, Geonpul woman of the Quandamooka First Nation and Indigenous Australian critical race theorist Moreton-Robinson asserts that race has shaped the development of institutions, such as law in Australia (and we would suggest musicology), in accordance with the 'possessive logic of white patriarchal sovereignty' (Moreton-Robinson 2004: 2). MoretonRobinson explains that patriarchal white sovereignty is a 'regime of power that derives from the illegal act of possession' (ibid.: 2) of Australian in 1788 by the English Crown under the false authority of the legal doctrine terra nullius (land belonging to no one). Similarly, from her standpoint as an Indigenous woman, legal scholar Irene Watson (2002: 253) describes terra nullius as a 'tale' with a capacity to bury Aboriginal and Torres Strait Islander peoples alive through its own white settler colonial desire to survive via the physical social, political, ontological, and epistemological possession of Indigenous Others, and in doing so, keep on burying. From this point on, the Crown held exclusive possession of the place now called Australia and 'confer[red] patriarchal white sovereignty' on its citizens', according to a mode of rationalisation that Moreton-Robinson 
describes as 'possessive logic'. Possessive logic operates ideologically, epistemologically, and discursively to 'naturalise the nation as a white possession' (Moreton-Robinson 2004: 2) and is 'underpinned by an excessive desire to invest in reproducing and reaffirming the nation-state's ownership, control and domination' (ibid.: 2). From our perspective, the move by Stephen and the MSA to instigate a 'Welcome to Country' as non-negotiable and standard MSA business was a step towards explicitly resisting the dominance of white noise through the sounding of a different system of musical knowledge.

Watson notes the ways in which a coloniality of being and a coloniality of power continue to operate through Aboriginalist and colonially complicit disciplines such as ethnomusicology, to construct Indigenous Australian identities through master texts that impose, mandate, and assume 'the power to create and the power to take identity' (2015: 73) and deny sovereignty. Described by McConaghy (2000) as Orientalism in the Australian context, Aboriginalism produces authoritative and essentialist 'truths' about who, what, why, and how Indigenous Australian peoples were, might, and can 'be'. Aboriginalism exists as a romantic and nostalgic celebration of a homogenised Indigenous Australian people as the 'noble savage'; fixed and locked as 'primitive' in a distant pre-colonial past, untainted by progress and development. Such images can be seen on the cover of several historical, anthropological, and music texts about Australian Indigenous peoples- the works of A. P. Elkin (1964) and Hiatt (1996) come to mind. For example, the solitary figure of a dark-skinned Aboriginal man, positioned in a remote location, standing on one leg, dressed in a lap-lap while holding a spear on the cover of A.P. Elkin's text (1964) could be read as highlighting the Aboriginalist assertion that Aboriginality is constituted by a remote, primitive, traditional, male Aboriginal culture. The cover of Hiatt's book (1996) depicts three Aboriginal men sitting on the ground, making a fire while another three Aboriginal men stand behind grass huts holding spears. Three women and two small children appear in the far background of the illustration barely visible to the reader's eye. One reading of this illustration could be that the artwork presents a picture from Australia's colonial past and that nonIndigenous people no longer view Aboriginal people in this way. However, the title of Hiatt's text, Arguments about Aborigines, emphasises that he engages in discussions 'about' rather than 'in dialogue' or 'with' Aboriginal people. This could be read as objectifying Aboriginal people and clearly does not suggest any engagement with Aboriginal people. While it is not 
apparent whether the painting was selected by Hiatt or by the publishers, when the cover is analysed in conjunction with the title of the book, the image illustrates Aboriginalism at play and highlights the Aboriginalist claim that Aboriginality is defined by a static, traditional culture. While these images could be entirely contemporary for some Aboriginal people, they could also be read as a convenient colonial narrative that reproduces the white fantasy of peaceful settlement and exercises a public pedagogy of forgetting in relation to the historical and ongoing effects of colonisation on Indigenous Australian peoples. Aboriginalism thus operates as a strand of colonial discourse that 'generally represents Aboriginality as having a pure and authentic quality untouched by historical and cultural change' (Bradford 2001: 15). Arguably, the move by the MSA to insist that a 'Welcome to Country' be performed at every national and state gathering, was a move to 'unforget' the colonial narrative and remember, perhaps even reinstate through the materiality and affective nature of performance, the sovereign status of Aboriginal and Torres Strait Islander peoples.

\section{As it happened: Key notes and moments in turning the colonial tide}

The 'MSA has a history of crossing boundaries', Stephen noted in his keynote address to the 21st National Conference of the MSA at the University of Adelaide in 1998. He continued:

It's scary to some, it challenges people's privileged positions, it keeps us all on edge. But it's the way forward, otherwise we will stagnate, we will become irrelevant to the cultural life of our country, our region, our world. Let us keep boundaries in mind and be on the lookout to cross them over the next few days and in the years ahead of us. (Wild 1999: 28)

In this address, Stephen specifically made mention of the relationship of the history of the MSA with the documentation and preservation of Aboriginal and Torres Strait Islander musics. Citing the work of Isaac Nathan, Alfred Haddon, Harold Davies, Trevor Jones, Alice Moyle, and Catherine Ellis as examples, he suggested that the discipline of ethnomusicology and the association more broadly, had begun on a premise of inclusivity and was embedded in long-standing research relationships with Indigenous Australian communities (Wild 1999: 22). He asked the MSA community to reconsider what that relationship might 
mean in contemporary practice, and how we might begin to celebrate the Australasian nature of the work of the MSA (ibid.: 23). It is important to note then that the 'Welcome to Country' policy did not take place in a vacuum but alongside a bigger-picture discussion of the relationship of the work of music researchers in Australia to the discipline of musicology as practised-and dominated-by Europe and North America. The marginalisation of theoretical, philosophical, and practical work being undertaken of scholars in the Global South by those in the Global North sat uncomfortably beneath the surface of Stephen's questioning of the relevancy of the word 'Musicology' in the name of our association.

Appealing to the work that music researchers do in serving 'humanity through music' (p. 27), Stephen put in place a discourse of change and a discourse of challenge. He foregrounded the need for the MSA to reconsider its disciplinary borders, which we read as colonial boundaries, to make space for those outside to cross over and become part of our music research community. Stephen's words continued to sow the seeds for formal recognition of Indigenous Australian peoples in the activities of the MSA, which had begun a year earlier. In 1997 at the national annual general meeting of the MSA held in Armidale, New South Wales, a motion was moved by Liz that the MSA 'mark the year 2000 as a year of reconciliation with the Indigenous peoples of the country, and that traditional owners are recognised at the place of an MSA event, in a manner appropriate to the MSA and to those owners' (MSA 1997). Seconded by Stephen, the tide had begun to turn.

Over the next year and a half, Stephen and Liz drafted the guidelines to the 'Welcome to Country'. They drew on Stephen's experiences working at the Australian Institute of Aboriginal and Torres Strait Islander Studies in Canberra and with Yolngu communities in Arnhem Land and Warlpiri people in Central Australia, and Liz's experience working in the Aboriginal and Torres Strait Islander Studies Unit at the University of Queensland and with Yanyuwa people from Burrulula, to formulate guidelines that reflected Indigenous and non-Indigenous agendas in relation to the formal recognition of Aboriginal and Torres Strait Islander peoples in MSA business. Liz remembers that while they were satisfied that the wording of the document reflected the political rationale behind the 'Welcome to Country' policy, neither she nor Stephen were confident that all members of the MSA would be prepared to support this initiative. 
At the 1999 MSA conference in Perth during a Special General Meeting, the members discussed a proposed amendment to the National Constitution to read: 'Indigenous custodians will be recognised at the principal place of all National MSA public events in a manner appropriate to the MSA and to the custodians'. Liz outlined the background to this proposed amendment along with the 'Welcome to Country' guidelines, and there was some discussion of the wording of Article VI, new By-Law $2 \mathrm{~d}$, the main purpose of which is to ensure that Indigenous custodians are recognised by the Society at Society events, such as national conferences. David Tunley asked about the procedure to be followed if no traditional owners could be located for an MSA event. Liz explained that it was quite appropriate in those circumstances for someone other than an indigenous custodian to welcome conference delegates on behalf of the traditional custodians. Society members at the Aboriginal and Torres Strait Islander Studies Unit at the University of Queensland would be happy to advise conference organisers in any case. Tunley remarked that he fully supported the Indigenous welcome ceremony that opened the 1999 MSA Conference at the University of Western Australia, and John Phillips noted that the inaugural Indigenous welcome at the 1998 MSA conference at the University of Adelaide had also been a successful and significant event (MSA 1999).

After lively debate about what terms like 'Indigenous' mean in relation to belonging to country, being Australian, and being sovereign peoples, at the 22nd meeting of the MSA (1999), a 'Welcome to Country' policy was unanimously endorsed by members; they are now included in the association's operations manual:

\section{Welcome to Country: Guidelines for the Recognition of Indigenous Culture and Custodianship of Country at National MSA Public Events}

\section{The policy}

Endorsed in June 1999, the 'Welcome to Country' policy of MSA recognises the Indigenous custodianship of country where MSA public events are held, and acknowledges the continuing significance of Indigenous culture in Australia. This policy embraces the spirit of reconciliation between Indigenous and other Australians and reflects the national process of reconciliation as guided by the national Council for Aboriginal Reconciliation. 
What Is Welcome to Country?

Recognition is made through a formal process called Welcome to Country. It always occurs in the opening ceremony of the event, preferably as the first item. Welcome to Country is conducted by a representative (or representatives) of local Indigenous custodians who welcome the delegates to their country. Indigenous protocols in relation to Welcome to Country are wide and diverse and will vary according to region and locality. The form of the welcome is negotiated between the Indigenous people and the event organisers. For example, Welcome to Country may consist of a single speech, or it may include some kind of performance (a song, dance, didjeridu solo, etc), or it may be a combination of these. It is important to remember that the Indigenous representative/s must feel comfortable with the arrangements. Rather than a gesture of tokenism and political correctness, MSA acknowledges that Welcome to Country is a right of the local Indigenous custodians and not a privilege.

\section{Who Performs Welcome to Country?}

Who performs Welcome to Country is agreed between appropriate representatives (individuals or organisation) of local Indigenous custodians and the event organisers. There are a number of channels through which event organisers may contact appropriate Indigenous people. These include the local campus Indigenous student support or study centre, a local Indigenous land council, an Aboriginal health centre, an Aboriginal legal service, or the local office of ATSIC (Aboriginal and Torres Strait Islander Commission). Officers of such organisations will be able to inform the event organisers of appropriate Indigenous people to contact. Contact should be made as early as possible in the planning of the event. It is traditional that some form of payment is made either to individuals or to an organisation for providing such a service. The exact form and amount of payment is negotiated between the Indigenous custodians and the event organisers.

\section{Reconciling music research in Australia: Truth, justice, and dialogue}

The landmark move by the MSA to include 'Welcome to Country' as standard business at national and state meetings and conferences can also be located clearly within national and global discourses of reconciliation. Discussions of reconciliation often include overcoming conflict but also encompass themes of peace, fairness, justice, healing, and forgiveness (Komesaroff 2008: 1). Theories of reconciliation cover many disciplines 
including social theory, history, psychology, law, philosophy, and theology. Here we focus on three interwoven themes that run through discourses of reconciliation: the search for truth and recognition of past wrongs, the hope for justice and healing, and dialogue. Rothfield suggests that the impetus behind reconciliation is in part to expose-for the record, for history-to make public that which has been committed to the dark' (2008: 15). Short agrees and notes that establishing the truth about past injustice and publicly acknowledging this history is the first logical step in any attempt at redress and reconciliation' (2008: 12). He also highlights that another theme in discourses of reconciliation is a concern for justice, and therefore healing, for victims of political atrocities and human rights violations. He provides examples such as South Africa's Truth and Reconciliation Commissions, which recommended legislation to establish payments, counselling, information about murdered relatives, medical treatment, and naming of schools and parks to therefore restore 'healing, harmony and reconciliation'. The possibility of engaging and continuing dialogue is another key feature of reconciliation. Komesaroff notes that 'untrammelled communication may not be possible but some kind of dialogical contact always is, at least where there is a readiness to pass beyond the tyranny of violence and fear' (Short 2008: 5). Lederach suggests that reconciliation involves the creation of a 'social space' where this communication across race, culture, religion and politics can occur (1999).

Certainly, as Komesaroff acknowledges, there is no general method for reconciliation because the practical process is 'subject to the local conditions in which it takes place' (2008: 6). In the Australian context, Huggins writes that in essence reconciliation is about recognising the rights of Aboriginal and Torres Strait Islander peoples to express their cultures, achieving respectful relationships between Indigenous and non-Indigenous Australians, and valuing and acknowledging difference (2008a: xv). Huggins notes that the period leading up to the 1967 referendum is often described as the start of reconciliation in Australia. Indigenous and non-Indigenous people campaigned together to ensure the referendum was passed so that Aboriginal and Torres Strait Islander peoples would be counted as Australians for the first time since Australia became a nation in 1901 (ibid.: xv). In 1991, the Council for Aboriginal Reconciliation (CAR) was founded to head a reconciliation process. During this time, other significant events occurred such as a national inquiry into the forcible removal of Aboriginal children from their 
families (Human Rights and Equal Opportunity Commission 1997), and the High Court recognised Indigenous peoples' native title rights to land. Many commentators view the year 2000 as a significant time for reconciliation when 400,000 people undertook the Walk for Reconciliation across Sydney Harbour Bridge, followed by other Corroboree 2000 bridge walks; people signed 'sorry books' and created displays of 'sea of hands'; and CAR handed their final report to the prime minister and the Commonwealth Parliament (Gunstone 2008). Reconciliation Australia was then founded to attempt to sustain reconciliation in Australia (Reconciliation Australia 2010).

Certainly, as Derrida points out, 'no one would decently dare object to the imperative of reconciliation' (2004: 50), yet there have been a number of critiques of reconciliation in Australia. Tatz noted that reconciliation in Australia was just a 'catchphrase adopted by opinionmakers to discern those who, stubbornly and wrongly, resist the entwined and 'synonymous' notions of 'forgive and forget' (1998: 2), while Moran suggested that reconciliation was only a 'new breed of settler nationalism' in Australia (1998: 107). Short agrees and also points to the paradox of the reconciliation process in Australia when:

despite these significant events at the end of the official process mandate, Indigenous peoples were still an excluded underclass; they had all the highest incidences of disease and respiratory infections and the lowest life expectancy. (Short 2008: 2)

Gratton's (2000) edited collection on Australian reconciliation processes also included doubts over the meaning of reconciliation in Australia with Reynolds questioning the role for non-Indigenous people: 'did reconciliation require anything of them beyond having to come to terms with a few home truths about the past which have been hidden away in the cupboard of forgotten things?' (Reynolds 2000: 53). Gunstone (2008) suggests that the success of CAR was limited, and there is still much confusion in the wider Australian community over the meaning of 'reconciliation'.

Reconciliation processes are certainly complex and encourage 'diverse and at times contrary viewpoints and strategies'. As Rothfield points out, 'reconciliation is incredibly important for counties like Australia, which has just begun to acknowledge past wrongs, and needs to address its continuing legacies of injustice' (2008: 26). In putting forward a 
change to the constitution to include a 'Welcome to Country' at national and state meetings and conferences, the MSA sought to practically and symbolically acknowledge the role that music and music research plays in creating a space to acknowledge the truth of Australian colonial history. The society intended to express hope for justice and healing; performing songs provides moments for (musical) dialogue between Indigenous and non-Indigenous people to take place.

\section{Waves of reform in the MSA}

One of the important conversations that Stephen's work on the MSA's 'Welcome to Country' brought about relates to the roles and responsibilities that ethnomusicologists and music researchers have in assisting to sustain Indigenous Australian music traditions. In 2003, a number of ethnomusicologist members of the MSA began an 'Indigenous music think tank', essentially a discussion forum, which would form part of annual MSA conferences. Initially led by Linda Barwick and Allan Marett, the purpose of the think tank each year is to provide an opportunity for ethnomusicologists and Indigenous performers attending the conference to discuss key questions and issues in relation to Indigenous Australian music research. The think tank has made space for ethnomusicologists working with Aboriginal and Torres Strait Islander communities to bring to the table an acute awareness of the challenges faced by communities to sustain their music traditions and discussion of the ways in which we might enact our white colonial power and privilege as researchers to further the agendas of Indigenous Australian peoples and performers. According to a 'Statement on Indigenous Australian Music and Dance', endorsed in 2011 by the International Council for Traditional Music-Australia and New Zealand Regional Committee, it is predicted that 98 per cent of song traditions have been lost since colonisation (International Council for Traditional MusicAustralia and New Zealand 2011), and ethnomusicologists continue to work closely with communities to sustain and document traditions that remain. Finding ways to continue the teaching and learning of songs within Aboriginal and Torres Strait Islander communities is discussed by many researchers as an increasingly difficult task for Indigenous Australian communities. The reasons for this include the realities of losing senior members of communities and with them the loss of song cultures, 
a lack of interest from younger generations, the need for individuals to move away from communities for education, health and employment opportunities, and family responsibilities (e.g. Barwick, Laughren, Turpin 2013; Campbell 2012; Mackinlay 2009; Magowan 2007).

The Indigenous music think tank has also opened up discussion of the practical steps that music researchers and ethnomusicologists might undertake together with Aboriginal and Torres Strait Islander communities to foreground and promote Indigenous Australian musical self-determination and sovereignty within our research. The absence of Indigenous music researchers within the MSA was identified very early on as a significant problem that needs attention in terms of turning the colonial tide and enabling Aboriginal and Torres Strait Islander voices to disrupt the white noise of coloniality in our discipline. Two of the immediate and practical measures that the MSA put in place were to: (1) provide a travel grant and scholarship for Aboriginal and Torres Strait Islander music researchers and performers to attend MSA conferences; and (2) ensure that an Indigenous music researcher and/or performer is considered as one of the keynote speakers at national conferences.

The role of technology in assisting Indigenous Australian communities to sustain their music traditions has been identified by the think tank as another important area for music researchers and ethnomusicologists to become more proactive. Indigenous Australian people are increasingly active in recording their own music, while ethnomusicologists also use technology to document songs in CDs, DVDs, and other multimedia (Neuenfeldt 2007). Audio and visual recording of performances within communities is also a way for Indigenous people to document their social histories and 'create counter-narratives to colonisation through the performance of song as story and survival' (Mackinlay 2010: 106). Recordings by ethnomusicologists are in fact becoming part of the sharing of knowledge between generations of performers, and as teaching and learning resources in schools (see Barwick, Laughren, and Turpin 2013). The repatriation of sound recordings made by previous generations of ethnomusicologists has also been another way for ethnomusicologists to assist communities in preserving and sometimes reviving traditions (see Campbell 2012). Dialogue between Indigenous communities and researchers about the role of technology is taking place because of 'the everincreasing use of IT to access, create and collate tangible and intangible 
cultural information and heritage [and] the torrent of new media and digitisation' (Australian Institute of Aboriginal and Torres Strait Islander Studies 2010). As Magowan notes, ongoing discussions with Indigenous communities about the use of technology is needed (2005: 71).

Close and continuing relationships between non-Indigenous ethnomusicologists and Indigenous people are central in assisting Indigenous communities in sustaining their traditions (e.g. Hayward 2005; Barney 2014; Mackinlay and Chalmers 2014), and this is a thread that runs strongly through the waves of reform that the MSA has put in place. This is echoed by Indigenous scholars in Australia who call for non-Indigenous researchers to enter into meaningful dialogues with Indigenous people to bring about a reconciled Australia. For example, Huggins argues that 'strong collaboration between Indigenous and nonIndigenous [people] ... is to be encouraged and supported wherever possible' (2008b: iv), while Nakata emphasises the need to develop and nurture working collaborations, 'relationships and dialogue at the level of scholarly knowledge production' (2004: 4). In terms of turning the colonial tide of the MSA, re-imagining and reconfiguring research relationships that might arguably be thought of as caught and complicit in the 'colonial matrix' (after Mignolo 2006) between Indigenous and non-Indigenous peoples is crucial. Maddison argues that the 'relationship between non-Indigenous and Indigenous Australia is profoundly stuck' (2011: 5). Despite all of the reforms mentioned here, there are still (with the exception of a small few) a limited number of Indigenous researchers undertaking ethnomusicological research, and the promises of selfdetermination and sovereignty that the 'Welcome to Country' heralded in would seem to be nothing but talk. However, the National Recording Project for Indigenous Performance in Australia has been playing an important part in promoting Indigenous researchers (see Corn and Ford 2014). Linked with this is the lack of Indigenous students studying music at tertiary level and the limited number of Indigenous academics who are involved with supporting Indigenous and non-Indigenous students (Page and Asmar 2008). Yet the research of ethnomusicologists working collaboratively with Indigenous people as co-researchers is a way to 'unstick' this relationship and work towards social justice for Indigenous people in Australia more generally (see Barney 2014). 


\section{Conclusion}

For us, other ethnomusicologists, and the broader MSA community of music researchers, the 'Welcome to Country' began a most necessary discussion about the colonial history and contemporary reality of the relationship between Indigenous and non-Indigenous peoples in our country. It was the beginning of an important discussion about why and how we must recognise Aboriginal and Torres Strait Islander peoples as first and sovereign peoples, and consider more deeply the ways in which our work as music researchers remains caught and complicit within coloniality. The discussions had by the MSA and its members, used and emphasised words such as 'reconciliation', 'hope', 'action', and 'social justice' as solutions to the ongoing impact of colonialism on the daily lives of Indigenous peoples and the urgent need for us as non-Indigenous researchers to own up to our place in colonial history, reconsider the ongoing role we have in such processes, and take some responsibility for doing our work differently. As we bring this chapter to a close, however, we would make a plea that the work that Stephen began to turn the colonial tide in the MSA is not lost, forgotten, or overlooked in the white noise of the neo-colonial/liberal moment in which we currently find ourselves. We would ask all of us in the music research community to resist complacency and refuse to rest in the comfort that such words bring us as nonIndigenous people. If we uncritically place reconciliation and social justice words in discourse around the colonial relationship between Indigenous and non-Indigenous people, it is possible that they provide white settler colonials such as ourselves with a place of belonging - a place where the performance of our identities as white settler colonial researchers has value, worth, authority, and power. It is possible that they provide us with 'immunity', as Youngblood Henderson (2000: 32) contends, from recognising and responding to ourselves as part of the problem. It is possible that in proclaiming to do social justice, reconciliation, and antiracist good, a policy such as 'Welcome to Country' becomes nothing but a metaphor for the very things it stands for (Tuck and Yang 2012). It is possible that the white noise of these words is heard as a coloniality of being that continues to exclude and dominate Indigenous Australian voices in music research and the MSA.

There is no doubt in our mind that 'Welcome to Country' is a policy that holds much promise for doing the kind of decolonial work it aspires to in relation to foregrounding Indigenous Australian sovereignties and 
counteracting the possessive logic of white patriarchal sovereignty in terms of the ways the MSA does business. The performance of such policy requires ongoing vigilance and attentiveness, and it is now up to the current generation of music researchers who follow in the steps of Stephen Wild to take up and continue the disciplinary turn towards decoloniality.

\section{Acknowledgements}

We would like to express our heartfelt thanks to John Phillips for the fantastic assistance he gave in searching through the MSA archives and providing us with essential historical documentation on the processes that took place to develop and ratify the 'Welcome to Country'. Thanks also to Steven Knopoff for his assistance in providing the current version of the MSA 'Welcome to Country' policy.

\section{References cited}

Australian Institute of Aboriginal and Torres Strait Islander Studies. 2010. 'Information Technologies and Indigenous Communities Conference.' aiatsis.gov.au/publications/products/ information-technologies-and-indigenous-communities.

Barney, Katelyn. 2014. ed. Collaborative Ethnomusicology: New Approaches to Music Research between Indigenous and Non-Indigenous Australians. Melbourne: Lyrebird Press.

Barney, Katelyn, Martin Nakata, and Cindy Shannon. 2014.

'Introduction: Exploring the Scope of the Australian Indigenous Studies Learning and Teaching Network.' The Australian Journal of Indigenous Education 43 (1): 1-7. doi.org/10.1017/jie.2014.2.

Barney, Katelyn, and Monique Proud. 2014. 'Collaborative Music

Research at the Contact Zone in Cherbourg, an Aboriginal Community in Queensland.' In Collaborative Ethnomusicology: New Approaches to Music Research between Indigenous and NonIndigenous Australians, edited by Katelyn Barney, 81-96. Melbourne: Lyrebird Press. 
Barney, Katelyn, and Lexine Solomon. 2010. Performing on the Margins: Conversations with Torres Strait Islander Women Who Perform Contemporary Music. St Lucia: Aboriginal and Torres Strait Islander Studies Unit.

Barwick, Linda, Mary Laughren, and Myfany Turpin. 2013. 'Sustaining Women's Yawulyu/Awelye: Some Practitioners' and Learners' Perspectives.' Musicology Australia 35 (2): 191-220. doi.org/10.1080/ 08145857.2013.844491.

Bradford, Clare. 2001. Reading Race: Aboriginality in Australian Children's Literature. Carlton, Vic: University of Melbourne Press.

Brown, Lilly. 2010. 'Nurturing Relationships within a Space Created by "Indigenous Ways of Knowing": A Case Study.' The Australian Journal of Indigenous Education 39 (supplement): 15-22.

Campbell, Genevieve. 2012. 'Ngariwanajirri, the Tiwi "Strong Kids Song": Using Repatriated Song Recordings in a Contemporary Music Project.' Yearbook for Traditional Music 44: 1-23. doi.org/10.5921/ yeartradmusi.44.0001.

Corn, Aaron, and Linda Payi Ford. 2014. 'Consensus and Collaboration in the Making of the National Recording Project for Indigenous Performance in Australia.' In Collaborative Ethnomusicology: New Approaches to Music Research between Indigenous and Non-Indigenous Australians, edited by Katelyn Barney, 115-28. Melbourne: Lyrebird Press.

Derrida, Jacques. 2004. 'On Forgiveness.' In Cosmopolitanism and Forgiveness by Jacques Derrida, 25-60. Trans. by Mark Dooley and Michael Hughes. London: Routledge.

Elkin, A. P. 1964. The Australian Aborigines: How to Understand Them. 4th ed. Sydney: Angus and Robertson.

Frankenberg, Ruth. 1993. White Women, Race Matters. Minneapolis: University of Minnesota Press.

Gratton, Michelle. 2000. Editor. Essays on Australian Reconciliation. Melbourne: Black Inc. 
Gunstone, Andrew. 2008. 'The Australian Reconciliation Process: An Analysis.' In Pathways to Reconciliation: Between Theory and Practice, edited by Philipa Rothfield, Cleo Fleming, and Paul A. Komesaroff, 169-78. Aldershot: Ashgate.

Harris, Cheryl I. 1993. 'Whiteness as Property.' Harvard Law Review 106: 1707-91. doi.org/10.2307/1341787.

Hayward, Philip. 2005. 'Culturally Engaged Research and Faciliation: Active Development Projects with Small Island Cultures.' Refereed Papers from the 1st International Small Island Cultures Conference, Kagoshima University Centre for the Pacific Islands, 7-10 February, 55-60. sicri-network.org/ISIC1/i.\%20ISIC1P\%20Hayward.pdf.

Hiatt, L. R. 1996. Arguments about Aborigines: Australia and the Evolution of Social Anthropology. Cambridge: Cambridge University Press.

Huggins, Jackie. 2008a. 'The Human Face of Indigenous Australia.' In Pathways to Reconciliation: Between Theory and Practice, edited by Philipa Rothfield, Cleo Fleming, and Paul A. Komesaroff, xiii. Aldershot: Ashgate.

—_. 2008b. 'Editorial.' The Australian Journal of Indigenous Education 38 (supplement): iv.

Human Rights and Equal Opportunity Commission. 1997. Bringing Them Home: National Inquiry into the Separation of Aboriginal and Torres Strait Islander Children from Their Families. Sydney: Human Rights and Equal Opportunity Commission.

International Council for Traditional Music-Australia and New Zealand. 2011. 'Statement on Indigenous Australian Music and Dance.' www. ictmusic.org/sites/default/files/documents/IAMD_statement.pdf.

Komesaroff, Paul A. 2008. 'Introduction; Pathways to Reconciliation: Bringing Diverse Voices into Conversation.' In Pathways to Reconciliation: Between Theory and Practice, edited by Philipa Rothfield, Cleo Fleming, and Paul A. Komesaroff, 1-12. Aldershot: Ashgate.

Lederach, John Paul. 1999. Sustainable Reconciliation in Divided Societies. Washington: United States Institute of Peace Press. 
Mackinlay, Elizabeth. 2008. 'Making Space as White Music Educators for Indigenous Australian Holders of Song, Dance and Performance Knowledge: The Centrality of Relationship as Pedagogy.' Australian Journal of Music Education 1: 2-6.

- 2009. 'In Memory of Music Research: An Autoethnographic, Ethnomusicological and Emotional Response to Grief, Death and Loss in the Aboriginal Community at Borroloola, Northern Territory.' In Musical Autoethnographies: Making Autoethnography Sing/Making Music Personal, edited by Brydie-Leigh Bartleet and Cathryn Ellis, 225-44. Bowen Hills, Qld: Australian Academic Press.

—. 2010. 'Big Women from Burrulula: An Approach to Advoacy and Applied Ethnomusicology with the Yanyuwa Aboriginal Community in the Northern Territory, Australia.' In Applied Ethnomusicology: Historical and Contemporary Approaches, edited by Klisala Harrison, Elizabeth Mackinlay, and Svanibor Pettan, 96-115. Newcastle upon Tyne: Cambridge Scholars Publishing.

_- 2011. 'Social Justice and Music Education: Engaging Our Thinking Hearts.' International Kodaly Bulletin 36 (2): 8-15.

Mackinlay, Elizabeth, and Gordon Chalmers. 2014. 'Remembrances and Relationships: Rethinking Collaboration in Ethnomusicology as Ethical and Decolonising Practice. In Collaborative Ethnomusicology: New Approaches to Music Research between Indigenous and NonIndigenous Australians, edited by Katelyn Barney, 63-79. Melbourne: Lyrebird Press.

Maddison, Sarah. 2011. The Real Challenge for Black-White Relations in Australia: Beyond White Guilt. Sydney: Allen and Unwin.

Magowan, Fiona. 2005. 'Dancing into Film: Exploring Yolngu Motion, Ritual and Cosmology in the Yirrkala Film Project.' In Landscapes of Indigenous Performance: Music, Song and Dance of the Torres Strait and Arnhem Land, edited by Fiona Magowan and Karl Neuenfeldt, 57-75. Canberra: Aboriginal Studies Press.

- 2007. Melodies of Mourning: Music and Emotion in Northern Australia. Perth: University of Western Australia Publishing. 
McConaghy, Cathryn. 2000. Rethinking Indigenous Education: Culturalism, Colonialism and the Politics of Knowing. Flaxton, Qld: Post Pressed.

McIntosh, Peggy. 1992. 'White Privilege.' Creation Spirituality (JanuaryFebruary): 33-35.

Mignolo, Walter D. 2006. 'Islamophobia/Hispanophobia: The (Re)Configuration of the Racial Imperial/Colonial Matrix.' Human Architecture: Journal of the Sociology of Self-Knowledge 5 (1). scholarworks.umb.edu/humanarchitecture/vol5/iss 1/3.

Moran, Anthony. 1998. 'Aboriginal Reconciliation: Transformations in Settler Nationalism.' Melbourne Journal of Politics Special Reconciliation 25: 107.

Moreton-Robinson, Aileen. 2004. 'The Possessive Logic of Patriarchal White Sovereignty: The High Court and the Yorta Yorta Decision.' Borderlands e-journal 3 .

Musicological Society of Australia. 1997. Musicological Society of Australia Newsletter 49.

—_. 1999. Musicological Society of Australia Newsletter 51.

Nakata, Martin. 2004. 'Ongoing Conversations about Aboriginal and Torres Strait Islander Research Agendas and Directions.' The Australian Journal of Indigenous Education 33: 1-6. doi.org/10.1017/ S1326011100600807.

Neuenfeldt, Karl. 2007. ed. 'Indigenous Peoples, Recording Techniques and the Recording Industry.' Special issue, The World of Music 49 (1).

Page, Susan, and Christine Asmar. 2008. 'Beneath the Teaching Iceberg: Exposing the Hidden Support Dimensions of Indigenous Academic Work.' The Australian Journal of Indigenous Education 37 (supplement): 109-17.

Radano, Ronald M., and Philip V. Bohlman. 2000. eds. Music and the Racial Imagination. Chicago: University of Chicago Press.

Reconciliation Australia. 2010. 'Who Is Reconciliation Australia?' www.reconciliation.org.au. 
Reynolds, Henry. 2000. 'A Crossroad of Conscience.' In Essays on Australian Reconciliation, edited by Michelle Gratton, 53-59. Melbourne: Black Inc.

Rothfield, Philipa. 2008. 'Evaluating Reconciliation.' In Pathways to Reconciliation: Between Theory and Practice, edited by Philipa Rothfield, Cleo Fleming, and Paul A. Komesaroff, 15-28. Aldershot: Ashgate.

Short, Damien. 2008. Reconciliation and Colonial Power: Indigenous Rights in Australia. Aldershot: Ashgate.

Tatz, Colin. 1998. Genocide in Australia. AIATSIS Research Discussion Paper, 8. Canberra: Australian Institute of Aboriginal and Torres Strait Islander Studies.

Tuck, Eve, and K. Wayne Yang. 2012. 'Decolonization Is Not a Metaphor.' Decolonization: Indigeneity, Education and Society 1 (1): $1-40$.

Watson, Irene. 2002. 'Buried Alive.' Law and Critique 13 (3): 253-69. doi.org/10.1023/A:1021248403613.

- 2015. Aboriginal Peoples, Colonialism and International Law: Raw Law. Abington: Routledge.

Wild, Stephen A. 1999. “"What's in a Name?" or "As Soon as You Cross One Boundary Another One Appears."' Musicological Society of Australia Newsletter 51 (August): 19-28. (Keynote address to the 21st National Conference of the Musicological Society of Australia).

Youngblood Henderson, James (Sákéj). 2000. 'The Context of the State of Nature.' In Reclaiming Indigenous Voice and Vision, edited by Marie Battiste, 12-38. Vancouver, BC: University of British Columbia Press. 
This text is taken from A Distinctive Voice in the Antipodes: Essays in Honour of Stephen A. Wild, edited by Kirsty Gillespie, Sally Treloyn and Don Niles, published 2017 by ANU Press, The Australian National University,

Canberra, Australia.

dx.doi.org/10.22459/DVA.07.2017.06 